\title{
Starvation-induced Physiological Responses and RNA/DNA Ratios in Rock Bream, Oplegnathus fasciatus, and Olive Flounder, Paralichthys olivaceus
}

\author{
†n-Seok Park ${ }^{1}$, Hyun Woo Gil ${ }^{1}$, Bong-Seok Kim², Kwan-Ha Park ${ }^{3}$ and Sung-Yong Oh$^{4}$ \\ ${ }^{I}$ Division of Marine Bioscience, College of Ocean Science and Technology, \\ Korea Maritime and Ocean University, Busan 49112, Korea \\ ${ }^{2}$ Inland Fisheries Research Institute, National Institute of Fisheries Science (NIFS), Cheongpyeung 12453, Korea \\ ${ }^{3}$ Dept. of Marine Life and Applied Sciences, Kunsan National University, Kunsan 54150, Korea \\ ${ }^{4}$ Tongyeong Marine Science Station, Korea Institue of Ocean Science \& Technology (KIOST), Ansan 15627, Korea
}

\begin{abstract}
In a 12-week experiment, the rock bream, Oplegnathus fasciatus, and olive flounder, Paralichthys olivaceus, were investigated to determine the effects of starvation on their physiological parameters. The protein and DNA contents of the starved fish were significantly higher than the initial values and those of the fed fish. The RNA contents and RNA/DNA ratios of the fed fish were significantly higher than those of the other groups $(P<0.05)$. The hematocrit, hemoglobin, red blood cells $(\mathrm{RBC})$, and mean corpuscular volume $(\mathrm{MCV})$ of the fed rock bream were significantly higher than at baseline $(P<0.05)$, whereas the mean corpuscular hemoglobin concentration $(\mathrm{MCHC})$ of the fed fish was lower than at baseline $(P<0.05)$. The hematocrit, hemoglobin, $\mathrm{RBC}$, and $\mathrm{MCHC}$ of the starved group were significantly lower than the baseline values, whereas the $\mathrm{MCV}$ of the starved group was significantly higher than the baseline value $(P<0.05)$. No significant difference in alanine aminotransferase was observed between the fed fish and baseline, whereas the starved fish value was significantly higher than the baseline value $(P>0.05)$. There were no significant differences in cortisol levels. However, the glucose level in the fed group was significantly higher than the baseline level and that in the starved group was significantly lower than the baseline level $(P<0.05)$.
\end{abstract}

Key words : Olive flounder, Physiological responses, RNA/DNA ratio, Rock bream, Starvation

\section{INTRODUCTION}

The rock bream, Oplegnathus fasciatus, and olive flounder, Paralichthys olivaceus (Temminck et Schlegel), are economically important species in the Korean aquaculture industry, and their hatcheries are often built in conjunction with other hatcheries. Because the rock bream and olive flounder are often used in raw and sliced fish signature dishes, the demand for them confers high commercial values (Park et al., 2003; An et al., 2006).

Most fish undergo periods of starvation during wintering, spawning, migration, and regional reductions in their food resources. However, fish can overcome starvation with biochemical, physiological, and behavioral strategies. The endogenous energy from basic metabolic stores is spent as the fish consume their own tissues to remain alive

\footnotetext{
Manuscript received September 11, 2017, Received in revised form September 15, 2017, Accepted September 17, 2017

$\dagger$ Corresponding Author : In-Seok Park, Division of Marine Bioscience, College of Ocean Science and Technology, Korea Maritime and Ocean University, Busan 49112, Korea. Tel: +82-51-410-4321, Fax: +82-51-404-4750, E-mail: ispark@kmou.ac.kr
}

This is an Open Access article distributed under the terms of the Creative Commons Attribution Non-Commercial License (http:// creativecommons.org/licenses/by-nc/3.0) which permits unrestricted non-commercial use, distribution, and reproduction in any medium, provided the original work is properly cited. 
during starvation (Weatherley \& Gill, 1987; Lee et al., 1999; Park et al., 2006). Consequently, a number of integrated biochemical and physiological changes have evolved in response to starvation. These contribute to a reduction in energy requirements, the preservation of protein (lean tissue) mass, the maintenance of an ongoing supply of glucose to the tissues (e.g., the nervous system), red blood cells (RBC), and the renal medulla (Iain, 2007).

The typical physiological stress response is generally independent of the type of stressor and includes rapid increases in plasma cortisol and glucose, and frequently a delayed reduction in electrolytes and osmotic pressure (Carmichael et al., 1984a, 1984b). Stress has been described as an energy drain (Barton \& Schreck, 1987), often resulting in the diversion of energy from growth to catabolic uses. The quantitative aspects of the physiological changes induced by stress depend on the acclimation temperature and the intensity and duration of the stress (Carmichael et al., 1984a; Davis et al., 1984). Culture practices that limit stress responses improve the survival and growth of the fish because these responses can increase disease susceptibility, reduce osmoregulatory capacity, reduce growth, and generally disrupt homeostasis (Davis et al., 1985; Barton et al., 1987).

Growth is largely a function of protein biosynthesis, a process in which RNA plays a key role. Protein turnover is linked to dynamic changes in RNA, with a strong bearing on fish robustness (Mustafa et al., 1991). Buckley (1979, $1980,1981)$ has demonstrated that the RNA/DNA ratio is a useful indicator of the nutritional condition and growth rates of larvae in the winter flounder, Pseudopleuronectes americanus, the cod, Gadus morhua, and the sand lance, Ammodytes americanus. Nucleic acids play a major role in growth and development. The amount of DNA is stable under changing environmental conditions and has been used as an indicator of biomass and cell number (Regnault \& Luquet, 1974; Dortch et al., 1983). RNA is directly involved in protein synthesis. Consequently, the relationship between RNA and DNA is an index of the cell's metabolic intensity and has been shown to be sensitive to feeding levels (Bulow, 1970). To shed more light on this issue, we analyzed the effects of starvation on the physiological characteristics and RNA/DNA ratios of the rock bream and olive flounder.

\section{MATERIALS AND METHODS}

The rock bream, Oplegnathus fasciatus (standard length $[\mathrm{SL}] \pm \mathrm{SD}: 15.9 \pm 0.76 \mathrm{~cm}$; body weight $[\mathrm{BW}] \pm \mathrm{SD}$ : $164.6 \pm 32.21 \mathrm{~g}$ ), and olive flounder, Paralichthys olivaceus (SL: $22.9 \pm 0.88 \mathrm{~cm}$; BW: $100.7 \pm 11.67 \mathrm{~g}$ ), were caught and transported to the Fishery Genetics and Breeding Science Laboratory of the Korea Maritime University, Korea, for the experiment. The feeding and starvation experiment began in August, 2011, and lasted for 12 weeks. Three experimental groups were established: the initial control group, the fed group, and the starved group. For two weeks before the experiment, all the fish were fed daily with commercial feed (E-Wha Oil \& Fat, Busan, Korea; $50 \%$ crude protein, $8 \%$ crude fat, $4 \%$ crude fiber, and $15 \%$ ash) until they stopped eating. During the experiment, the fed group was hand fed three times daily at 4 $\mathrm{h}$ intervals. The fed group received food ad libitum, whereas the starved group was fasted for eight weeks.

A water recirculation system was used, in which 20 individuals were housed in a 1.1 ton fiber-glass-reinforced plastic circular tank $(118 \mathrm{~cm}$ diameter $\times 100 \mathrm{~cm}$ depth $)$. Each experimental group was cultured in two tanks. Light was provided with four $40 \mathrm{~W}$ fluorescent bulbs controlled by an electric timer, which maintained the photoperiod on a 14 : 10 light : dark cycle. No lights were used during the dark period. The water temperature was controlled automatically and maintained at $22 \pm 0.6^{\circ} \mathrm{C}$ during the experimental period.

Blood samples were collected from the caudal blood vessel complex using heparinized syringes in 1 min with- 
out anesthesia. The hematocrit, hemoglobin, and RBC were immediately analyzed with an autohematology analyzer (Excel 500; Danam Electronics, Dallas, TX, USA). The mean corpuscular hemoglobin $(\mathrm{MCH})$ was calculated as $\mathrm{MCH}=$ hemoglobin/ $\mathrm{RBC} \times 10$ (formulation), mean corpuscular hemoglobin concentration (MCHC) was calculated as $\mathrm{MCHC}=$ hemoglobin/hematocrit $\times 10$ (formulation), and the mean corpuscular volume (MCV) was calculated as $\mathrm{MCV}=$ hematocrit/RBC $\times 10$ (formulation). The blood samples were kept on ice in $1.5 \mathrm{~mL}$ polypropylene microcentrifuge tubes for less than $5 \mathrm{~min}$ before centrifugation at 13,000 rpm for $5 \mathrm{~min}$. The plasma was then collected and stored in a deep freezer (SW-UF-200; Samwon Freezer Engineering, Busan, Korea) at $-80^{\circ} \mathrm{C}$ until analysis.

The plasma cortisol concentrations were measured by radioimmunoassay (RIA; Donaldson, 1981). Cortisol was determined in $50 \mu \mathrm{L}$ samples using an RIA kit (Coat-ACount TKCO Cortisol RIA Kit; DPC, USA). Mixtures of samples in $100 \mathrm{~mL}$ of antiserum were incubated for $45 \mathrm{~min}$ at $37^{\circ} \mathrm{C}$, after which $1,000 \mathrm{~mL}$ of separation reagent was added. The mixture was placed in a refrigerator at $4{ }^{\circ} \mathrm{C}$ for $15 \mathrm{~min}$ and then centrifuged at $1,200 \times \mathrm{g}$ for $15 \mathrm{~min}$. The supernatant was assayed for $\gamma$-radiation using an automatic $\gamma$-counter (Cobra; Packard, USA). Glucose, $\mathrm{Na}^{+}, \mathrm{Cl}^{-}, \mathrm{K}^{+}$, aspartate aminotransferase (AST), and alanine aminotransferase (ALT) were analyzed using an automatic chemical analyzer (Vitros DT60, Vitros DTE, DTSC Chemistry System; Johnson and Johnson Clinical Diagnostics, New York,
NY, USA). Osmolality was analyzed with a micro osmometer (3MO Plus; Advanced Instruments, Norwood, MA, USA).

Protein was analyzed using a Sigma kit (Product code TPO 200, USA), according to the procedures of Lowery et al. (1951) and Ohnishi \& Barr (1978). The RNA/DNA ratio was measured according to the methodology of SchmidtThannhauser-Schneider (Schneider 1957). The experiment was performed in triplicate and the results are reported as means \pm standard deviations, unless otherwise stated. The data were analyzed with one-way ANOVA with the SPSS statistical package. The means were compared using Duncan's multiple range test and considered significantly different at $P<0.05$.

\section{RESULTS}

The protein and nucleic acid (total DNA and RNA) contents and the RNA/DNA ratio in the liver tissues of the rock bream, Oplegnathus fasciatus, are shown in Table 1. The protein content of the starved group was significantly higher than those of the initial and fed groups $(P<0.05)$. The DNA content of the starved group was significantly higher than those of the other groups, whereas the RNA content of the fed group was significantly higher than those of the other groups $(P<0.05)$. The RNA/DNA ratio of the fed group was significantly higher than those of the initial and starved groups $(P<0.05)$.

Table 1. Protein and nucleic acid (total DNA and RNA) contents and RNA/DNA ratios in the liver tissues of the initial, fed, and starved groups of rock bream, Oplegnathus fasciatus"

\begin{tabular}{ccccc}
\hline \hline & Protein $(\mathrm{mg} / \mathrm{g})$ & DNA $(\mathrm{mg} / \mathrm{g})$ & RNA $(\mathrm{mg} / \mathrm{g})$ & RNA-DNA ratio \\
\hline Initial & $417.7 \pm 1.31^{\mathrm{a}}$ & $0.3 \pm 0.05^{\mathrm{a}}$ & $1.7 \pm 0.43^{\mathrm{a}}$ & 4.87 \\
Fed & $16.1 \pm 1.75^{\mathrm{a}}$ & $0.5 \pm 0.03^{\mathrm{b}}$ & $2.6 \pm 0.39^{\mathrm{b}}$ & 5.50 \\
Starved & $24.2 \pm 6.73^{\mathrm{b}}$ & $0.7 \pm 0.06^{\mathrm{c}}$ & $1.4 \pm 0.10^{\mathrm{a}}$ & 1.94 \\
\hline
\end{tabular}

${ }^{*}$ Data are means $\pm \mathrm{SD}$ ( $n=10$ for each group). In each column, means with different lower-case superscript letters are significantly different (Duncan's multiple range test, $P<0.05$ ). 
The protein and nucleic acid (total DNA and RNA) contents and the RNA/DNA ratios in the liver tissues of the olive flounder, Paralichthys olivaceus, are shown in Table 2. The protein content of the starved group was higher than those of the initial and fed groups $(P<0.05)$. The DNA content of the starved group was significantly higher than those of the other groups, whereas the RNA content of the starved group was significantly lower than those of the other groups $(P<0.05)$. The RNA/DNA ratio of the fed group was significantly higher than those of the initial and starved groups $(P<0.05)$.

The variations in the hematocrit, hemoglobin, $\mathrm{RBC}$, $\mathrm{MCH}, \mathrm{MCHC}$, and $\mathrm{MCV}$ in the blood of the initial, fed, and starved groups of rock bream are shown in Table 3. The hematocrit, hemoglobin, RBC, and MCV of the fed group were significantly higher than those of the initial group $(P<0.05)$, whereas the MCHC of the fed group was significantly lower than that of the initial group $(P<0.05)$.

The hematocrit, hemoglobin, $\mathrm{RBC}$, and $\mathrm{MCHC}$ of the starved group were significantly lower than that of the initial group, and the MCV of the starved group was significantly higher than those of the initial group $(P<0.05)$. There was no significant difference in the $\mathrm{MCH}$ of the fed and starved fish $(P>0.05)$.

The variations in the osomlality, $\mathrm{Cl}^{-}, \mathrm{K}^{+}, \mathrm{Na}^{+}, \mathrm{AST}$, and ALT levels in the plasmas of the initial, fed, and starved groups of rock bream are shown in Table 4 . There were no significant differences in the osmolality, $\mathrm{Cl}^{-}, \mathrm{Na}^{+}$, or $\mathrm{K}^{+}$ levels of the fed and initial groups $(P>0.05)$; nor were there statistically significant differences in the osmolality, $\mathrm{Na}^{+}, \mathrm{Cl}^{-}$, and $\mathrm{K}^{+}$levels of the starved and initial groups $(P>0.05)$. No significant differences were observed in AST or ALT between the fed and initial groups $(P>0.05)$, whereas only ALT of the starved fish was significantly higher than that of the initial test specimens $(P<0.05)$.

The variations in the plasma glucose and cortisol levels of the initial, fed, and starved rock bream are shown in Fig. 1. There were no significant differences in the cortisol or

Table 2. Protein and nucleic acid (total DNA and RNA) contents and RNA/DNA ratios in the liver tissues of the initial, fed, and starved groups of rock bream, Paralichthys olivaceus*

\begin{tabular}{ccccc}
\hline \hline & Protein $(\mathrm{mg} / \mathrm{g})$ & DNA $(\mathrm{mg} / \mathrm{g})$ & RNA $(\mathrm{mg} / \mathrm{g})$ & RNA-DNA ratio \\
\hline Initial & $3.9 \pm 7.92^{\mathrm{a}}$ & $0.3 \pm 0.12^{\mathrm{a}}$ & $1.8 \pm 0.33^{\mathrm{a}}$ & 6.23 \\
Fed & $38.1 \pm 1.22^{\mathrm{a}}$ & $0.2 \pm 0.07^{\mathrm{b}}$ & $1.8 \pm 0.25^{\mathrm{b}}$ & 9.56 \\
Starved & $45.3 \pm 1.28^{\mathrm{b}}$ & $0.5 \pm 0.06^{\mathrm{c}}$ & $1.5 \pm 0.02^{\mathrm{a}}$ & 3.48 \\
\hline
\end{tabular}

${ }^{*}$ Data are means $\pm \mathrm{SD}$ ( $n=10$ for each group). In each column, means with different lower-case superscript letters are significantly different (Duncan's multiple range test, $P<0.05$ ).

Table 3. Blood analysis of the initial, fed, and starved groups of rock bream, Oplegnathus fasciatus*

\begin{tabular}{ccccccc}
\hline Group & $\begin{array}{c}\text { Hematocrit } \\
(\%)\end{array}$ & $\begin{array}{c}\text { Hemoglobin } \\
(\mathrm{g} / \mathrm{dL})\end{array}$ & $\begin{array}{c}\mathrm{RBC} \\
(\mathrm{Mil} / \mathrm{uL})\end{array}$ & $\begin{array}{c}\mathrm{MCH} \\
(\mathrm{pg})\end{array}$ & $\begin{array}{c}\text { MCHC } \\
(\mathrm{g} / \mathrm{dL})\end{array}$ & $\begin{array}{c}\text { MCV } \\
(\mathrm{fL})\end{array}$ \\
\hline Initial & $37.1 \pm 6.04^{\mathrm{b}}$ & $7.2 \pm 1.00^{\mathrm{b}}$ & $2.6 \pm 0.30^{\mathrm{b}}$ & $27.8 \pm 1.63^{\mathrm{a}}$ & $19.6 \pm 2.00^{\mathrm{b}}$ & $143.0 \pm 15.67^{\mathrm{a}}$ \\
Fed & $52.8 \pm 3.98^{\mathrm{c}}$ & $8.7 \pm 1.22^{\mathrm{c}}$ & $3.0 \pm 0.30^{\mathrm{c}}$ & $29.1 \pm 3.77^{\mathrm{a}}$ & $16.4 \pm 1.61^{\mathrm{a}}$ & $177.2 \pm 15.12^{\mathrm{c}}$ \\
Starved & $33.8 \pm 6.04^{\mathrm{a}}$ & $6.1 \pm 0.74^{\mathrm{a}}$ & $2.1 \pm 0.27^{\mathrm{a}}$ & $29.5 \pm 2.50^{\mathrm{a}}$ & $18.5 \pm 2.55^{\mathrm{a}}$ & $161.1 \pm 15.66^{\mathrm{b}}$ \\
\hline
\end{tabular}

${ }^{*}$ Data are means $\pm \mathrm{SD}(n=10$ for each group). In each column, means with different lower-case superscript letters are significantly different (Duncan's multiple range test, $P<0.05$ ). 
glucose levels of the fed and initial groups $(P>0.05)$. However, the glucose level of the starved group was significantly lower than that of the initial group $(P<0.05)$, whereas no significant difference was observed in the cortisol levels of the starved and initial groups $(P>0.05)$.

Fig. 2 shows the external and internal morphology of the

Table 4. Variations in osmolality, $\mathrm{Cl}^{-}, \mathrm{Na}^{+}, \mathrm{K}^{+}, \mathrm{AST}$, and ALT levels in the plasma of the initial, fed, and starved groups of rock bream, Oplegnathus fasciatus ${ }^{*}$

\begin{tabular}{cccc}
\hline & Initial group & Fed group & Starved group \\
\hline Osmolality $\left(\mathrm{mOsm} / \mathrm{kgH}_{2} \mathrm{O}\right)$ & $363.6 \pm 11.82^{\mathrm{ab}}$ & $374.0 \pm 13.17^{\mathrm{b}}$ & $349.0 \pm 6.00^{\mathrm{a}}$ \\
$\mathrm{Cl}^{-}(\mathrm{mmol} / \mathrm{L})$ & $149.8 \pm 3.56^{\mathrm{a}}$ & $153.0 \pm 1.87^{\mathrm{a}}$ & $150.2 \pm 2.77^{\mathrm{a}}$ \\
$\mathrm{K}^{+}(\mathrm{mmol} / \mathrm{L})$ & $3.0 \pm 0.58^{\mathrm{ab}}$ & $2.4 \pm 0.26^{\mathrm{a}}$ & $3.4 \pm 0.60^{\mathrm{b}}$ \\
$\mathrm{Na}^{+}(\mathrm{mmol} / \mathrm{L})$ & $178.0 \pm 3.32^{\mathrm{b}}$ & $180.4 \pm 3.78^{\mathrm{b}}$ & $171.2 \pm 2.59^{\mathrm{a}}$ \\
$\mathrm{AST}(\mathrm{IU} / \mathrm{L})$ & $57.8 \pm 32.12^{\mathrm{a}}$ & $25.0 \pm 14.68^{\mathrm{a}}$ & $78.4 \pm 59.44^{\mathrm{a}}$ \\
$\mathrm{ALT}(\mathrm{IU} / \mathrm{L})$ & $5.6 \pm 3.21^{\mathrm{a}}$ & $5.3 \pm 1.26^{\mathrm{ab}}$ & $10.2 \pm 4.15^{\mathrm{b}}$ \\
\hline
\end{tabular}

${ }^{*}$ Data are means $\pm \mathrm{SD}$ ( $n=10$ for each group). In each column, means with different lower-case superscript letters are significantly different (Duncan's multiple range test, $P<0.05$ ).
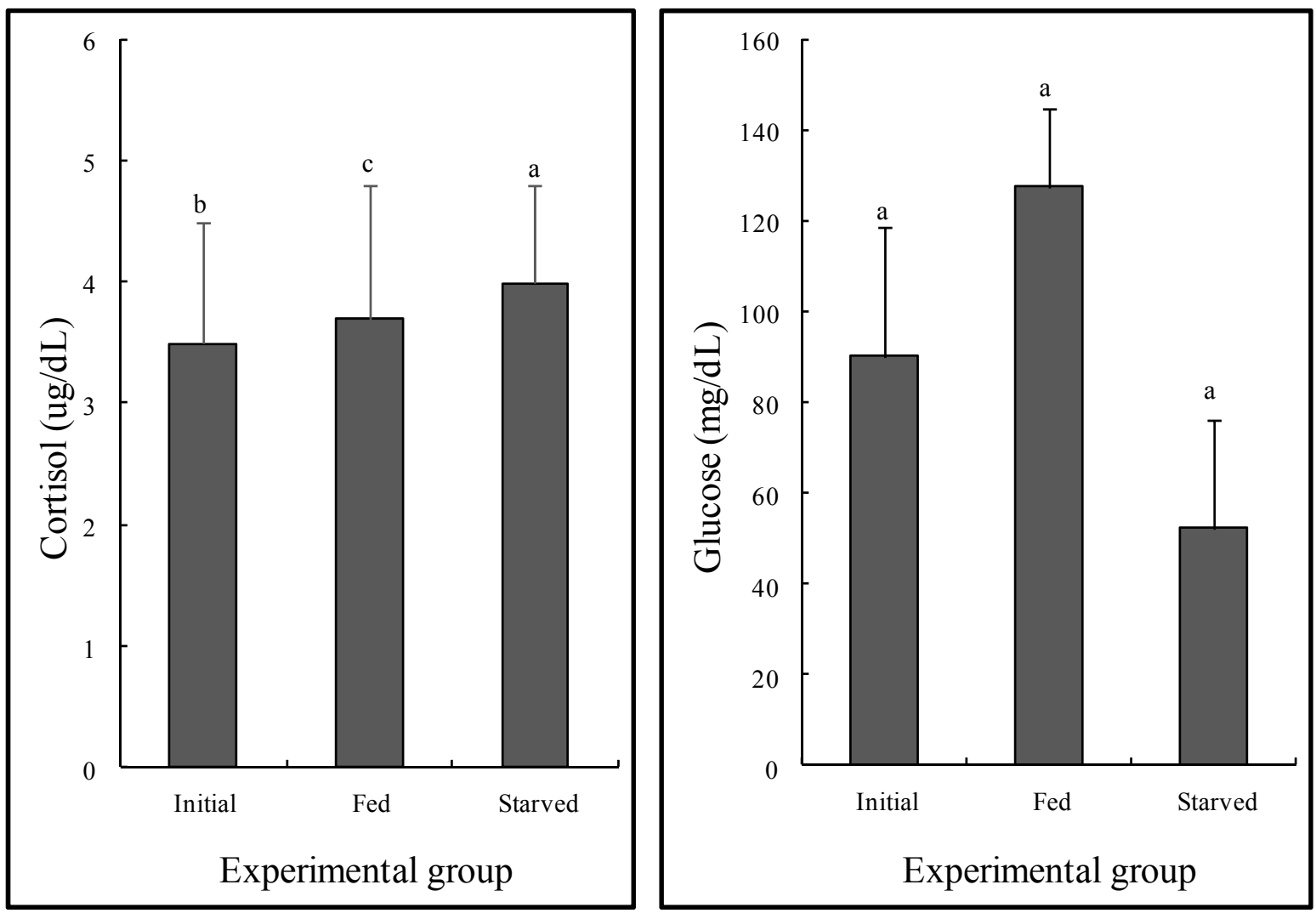

Fig. 1. Variations in cortisol and glucose in the plasma of the initial, fed, and starved groups of rock bream, Oplegnathus fasciatus. The same letters on the error bars indicate that they are not significantly different $(P>0.05)$. 


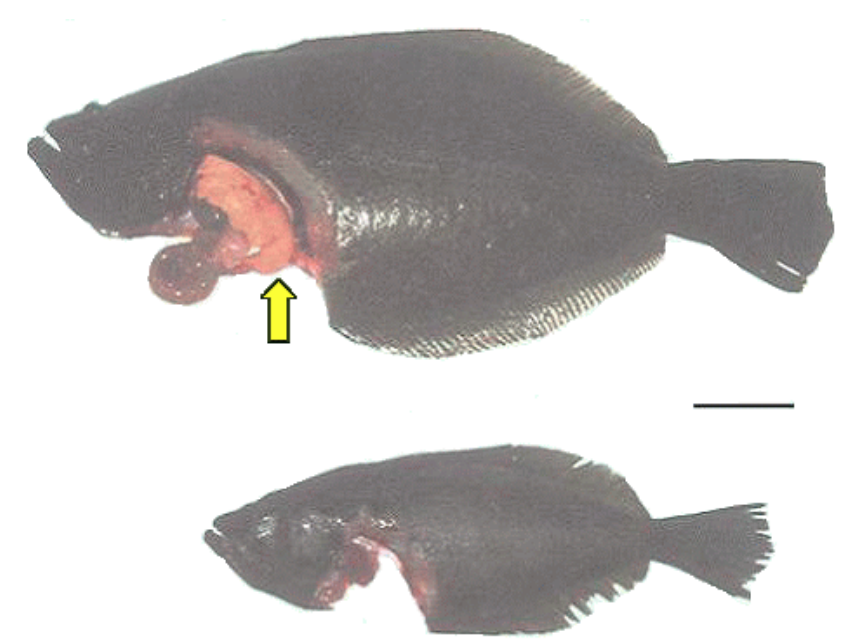

Fig. 2. External and internal morphology of the olive flounder, Paralichthys olivaceus: (a) fed and (b) starved for 12 weeks. Note the enlarged liver of the fed fish (arrowed). Bar is $4 \mathrm{~cm}$.

fed and starved olive flounder after the 12-week experimental period. The livers of the fed fish, which were yellowish brown in color, appeared to cover the visceral mass of the abdominal region, whereas deposits of abdominal fat around the livers appeared to suggest fatty liver disease (Fig. 2a). However, the liver color in the starved fish was scarlet and appeared diminished, and the gall bladder was dark green and larger than that in the fed fish (Fig. 2b).

\section{DISCUSSION}

Larsson \& Lewander (1973) noted that many fish undergo natural periods of starvation and have consequently evolved the capacity to withstand prolonged food deprivation. Such periods may extend to weeks, months, or even years and may cause extensive loss of energy stores in the body as the fish consumes its own tissues to remain alive (Love, 1970, 1980; Weatherley \& Gill, 1987).

In this study, our analysis of the rock bream, Oplegnathus fasciatus, and the olive flounder, Paralichthys olivaceus, showed that the protein contents of the starved groups increased. This suggests that the accumulation of fat in the livers of the fed fish caused a decline in liver cell content per unit liver weight. Conversely, prolonged food deprivation led to the internal metabolic consumption of the fat from liver tissues. As a result, the cytoplasm in the liver tissue decreased, whereas the liver cell content per unit liver weight increased. The increased DNA contents of the starved fish suggest that the active catabolism of structural materials, like protein, fat, and carbohydrate, reduced the ground substance and cell weight, whereas the liver cell content per unit liver weight increased as the DNA content per unit liver weight increased.

In the starved fish, the RNA content decreased compared with that of the initially tested rock bream and olive flounder. The RNA content of the liver tissue depends on the protein derived from feeding. As a result, feeding without a supply of protein or complete starvation leads to a reduction in the RNA content (Brachet, 1955). Brouche et al. (1970) also reported that reductions in the protein and RNA contents are induced by starvation.

The RNA/DNA ratio in fish tissue is associated with their feeding and growth rates (Haines, 1973; Buckley, 1979). The fed group displayed relatively lower protein and DNA contents, whereas their RNA content and RNA/ DNA ratio were higher than those in the starved group. Based on these results, we conclude than the fed rock bream and olive flounder actively synthesized protein. The analysis of RNA content is a sensitive method for measuring individual growth (Bulow, 1970), whereas the DNA content is fixed and can be characterized by a numerical index (Dortch et al., 1983). Because the RNA/DNA ratio is not affected by the cell content or cell size in tissues, it is a more appropriate parameter than the RNA content to measure cell growth (Haines, 1973).

The hematocrit, hemoglobin, and RBC of the starved rock bream increased. These results are similar to those for the European eel, Anguilla anguilla (Larsson \& Lewander, 1973). Love (1970) reported that the reduced hematocrit during starvation could reduce the production of new RBC. 
However, our results show that the $\mathrm{MCH}$ of the starved rock bream did not differ significantly from that of the initially tested fish. The hematocrit levels increased during starvation in the rainbow trout, Oncorhynchus mykiss, and the pick, Esox lucius (Ince \& Thorpe, 1976). Hematocrit levels are often elevated during stress to increase the oxygen supply to the major organs in response to the higher metabolic demand (Ruane et al., 1999). Therefore, differences in the hematocrit levels during stress may be species specific.

The plasma levels of $\mathrm{Cl}^{-}, \mathrm{K}^{+}$, and $\mathrm{Na}^{+}$in the starved rock bream were not significantly different from those in the fed fish, whereas osmolality decreased in the starved fish. Based on these results, we suggest that starvation disturbs the regulation of osmotic pressure. In other words, fish require abundant energy for the maintenance of homeostasis. Therefore, when the energy available to regulate osmotic pressure decreases, the regulation of osmotic pressure is disrupted.

Glucose formation increased simultaneously with increased quantities of cortisol. Elevated cortisol secretion under stress increases the activation of plasma glucose by increasing gluconeogenetic enzyme activity, which is induced by the first stress reaction (as a response to hormone) (Barton \& Iwama, 1991). The starved group exhibited increased levels of cortisol, although the difference was not statistically significant. However, glucose decreased in the starved group, which suggests that the response to the hormone is abolished by long-term starvation $(P<0.05)$.

Although the AST and ALT levels in the starved group increased, the difference for AST was not significant. AST and ALT are aminotransferases that occur in organs such as the liver and spleen, displaying low activity when fish are in good condition. However, their activity increases when the cells die from disease or unknown causes. We suggest that the increased AST and ALT levels of the starved fish relative to those of the initial group are attributable to physiological changes in organs such as the liver and spleen.

These experiments were undertaken to investigate physiology responses and DNA and RNA contents in the rock bream and olive flounder during starvation and feeding and to ascertain their growth and nutrition status. These experiments also provide information that should be useful for the aquaculture of both species.

\section{ACKNOWLEDGMENTS}

The authors thank the technical staff of the Laboratory for Fishery Genetics and Breeding Science at Korea Maritime University, Korea, for their helpful support, and the anonymous reviewers who greatly improved the quality of this manuscript. All procedures used in this study complied with the current laws of Korea (Ordinance of Agriculture, Food and Fisheries, no. 1, and that pertaining to experimental animals, no. 9982).

\section{REFERENCES}

An HS, Kim JW, Park JY (2006) Microsatellite DNA loci in the rock bream Oplegnathus fasciatus. Mole Ecol 6: 44-46.

Barton BA, Iwama GK (1991) Physiological changes in fish from stress in aquaculture with emphasis on the response and effects of corticosteroids. Ann Rev Fish Dis $1: 3-26$

Barton BA, Schreck CB (1987) Metabolic cost of acute physical stress in juvenile steel-head. Trans Amer Fisher Soc 116:257-263.

Barton BA, Schreck CB, Barton LD (1987) Effects of chronic cortisol administration and daily acute stress on growth, physiological conditions and stress responses in juvenile rainbow trout. Dis Aquat Organisms 2:173185.

Brachet J (1955) The biological role of the pentose nucleic acids. Page 576 in E. Chargaff and J. N. Davidson, edi- 
tors. The Nucleic Acids, Chemistry and Biology. Academic Press, New York, New York, USA.

Brouche G, Creach Y, Gas N (1970) Fasting and renutrition of carp, Cyprinus carpio (L.), I. Influence on the nucleic acids of liver. Archives des Sciences Physiologiques 24:243-251.

Buckely LJ (1981) Biochemical changes during ontogenesis of cod, Gadus morhua, and winter flounder, Pseudopleuronectes americanus, larvae. Rapports et Procesverbaux des Réunions. Conseil International pour l'Éxploration de la Mer 178:547-552.

Buckley LJ (1979) Relationshop between RNA/DNA ratio, prey density and growth rate in Atlantic cod, Gadus morhua, larvae. J Fish Res Board Can 36:1497-1502.

Buckley LJ (1980) Changes in ribonucleic acid, deoxyribonucleic acid and protein content during ontogenesis in winter flounder, Pseudopleuronectes americanus, and the effect of starvation. Fish Bull 77:703-708.

Bulow FJ (1970) RNA/DNA ratios as indicators of recent growth rates of a fish. J Fish Res Board Can 27:23432349.

Carmichael GJ, Tomasso JR, Simco BA, Davis KB (1984a) Confinement and water quality-induced stress in largemouth bass. Trans Amer Fisher Soc 113:767-777.

Carmichael GJ, Tomasso JR, Simco BA, Davis KB (1984b) Characterization and alleviation of stress associated with hauling largemouth bass. Trans Amer Fisher Soc 113:778-785.

Davis KB, Suttle MA, Parker NC (1984) Biotic and abiotic influences on corticosteroid hormone rhythms in channel catfish. Trans Amer Fisher Soc 113:414-421.

Davis KB, Torrance P, Parker NC, Suttle MA (1985) Growth, body composition and hepatic tyrosine aminotransferase activity in cortisol-fed channel catfish, Ictalurus punctatus Rafinesque. J Fish Biol 27:177-184.

Donaldson EM (1981) The pituitary-interrenal axis as an indicator of stress in fish. Pages 11-47 in A. D. Pickering, editor. Stress in Fish. Academic Press, London, UK.
Dortch Q, Roberts TL, Clayton Jr JR, Ahmed IS (1983) RNA/DNA rations and DNA concentrations as indicators of growth rage and biomass in planktonic marine organisms. Mar Ecol Prog Ser 13:61-71.

Haines TA (1973) An evalution of RNA-DNA ratio as a measure of long-term growth in fish populations. J Fisher Res Board Can 30:195-199.

Iain C (2007) Starvation, exercise, injury and obesity. Anaesth Intens Care Medi 8:299-303.

Ince BW, Thorpe A (1976) The effects of starvation and force-feeding on the metabolism of the northern pick, Esox lucius (L.). J Fish Biol 8:79-88.

Larsson A, Lewander K (1973) Metabolic effects of starvation in the eel, Anguilla anguilla L. Comp Biochem Physiol 44:367-374.

Lee K-K, Kim YH, Park I-S (1999) Effect of starvation on some nutritional parameters in Rhynchocypris oxycephalus. 1. Characterictics of the histological and biochemical changes. Kor J Ichthyol 11:33-41.

Love RM (1970) The chemical biology of fishes: with a key to the chemical literature. Pages 222-257 in R. M. Love, Editor. Depletion. Academic Press, London, UK.

Love RM (1980) The chemical biology of fishes, volume 2. Advances 1968-77. Pages 133-229 in R. M. Love, editor. Feeding and Starvation. Academic Press, London, UK.

Lowery OH, Rosebrough JN, Farr AL, Randall RJ (1951) Protein measurement with frolin phenol reagent. J Biol Chem 130:265-275.

Mustafa S, Lagardère J-P, Pastoureaud A (1991) Condition indices and RNA : DNA ratio in overwintering European sea bass, Dicentrarchus labrax, in salt marshes along the Atlantic coast of France. Aquaculture 96:367374.

Ohnishi ST, Barr JK (1978) A simplified method of quantitiating protein using the buiret and phenol reagents. Anal Biochem 86:193.

Park I-S, Nam YK, Douglas SE, Johnson SC, Kim DS 
(2003) Genetic characterization, morphometric and gonad development of induced hybrids between yellowtail flounder, Pleuronectes ferrugineus (Storer) and winter flounder, Pleuronectes americanus (Walbaum). Aquacult Res 34:389-396.

Park I-S, Woo SR, Kim E-M, Cho SH (2006) Effect of feeding and starvation on growth and phenotypic trait in olive flounder, Paralichthys olivaceus (Temminck et Schlegel). J Aquacult 19:183-187.

Regnault M, Luquet P (1974) Study by evolution of nucleic acid content of prepuberal growth in the shrimp, Crangon vulgaris. Mar Biol 25:291-298.

Ruane NM, Wendelaar Bonga SE, Balm PHM (1999) Diffe- rences between rainbow trout and brown trout in the regulation of the pituitary-interrenal axis and physiological performance during confinement. Gen Comp Endocrin 115:210-219.

Schneider WC (1957) Determination of nucleic acids in tissues by pentose analysis, Volume 3. Page 1154 in Wchneiger, W. C., editor. Methods in Enzymology. Academic Press, New York, New York, USA.

Weatherley AH, Gill HS (1987) The biology of fish growth, Volume 4. Pages 139-146 in Weatherley, A. H and H. S. Gill, editors. Protein, Lipid and Caloric. Academic Press, London, UK. 